\title{
Meta-barcoding in combination with palynological inference is a potent diagnostic marker for honey floral composition
}

\author{
Rama Chandra Laha ${ }^{{ }^{*} \dagger}$, Surajit De Mandal ${ }^{1 \dagger}$, Lalhmanghai Ralte ${ }^{1}$, Laldinfeli Ralte ${ }^{1}$, Nachimuthu Senthil Kumar ${ }^{1}$, \\ Guruswami Gurusubramanian', Ramalingam Satishkumar², Raja Mugasimangalam³ \\ and Nagesh Aswathnarayana Kuravadi ${ }^{4}$
}

\begin{abstract}
Identification of floral samples present in honey is important in order to determine the medicinal value, enhance the production of honey as well as to conserve the honey bees. Traditional approaches for studying pollen samples are based on microscopic observation which is laborious, time intensive and requires specialized palynological knowledge. Present study compares two composite honey metagenome collected from 20 samples in Mizoram, Northeast India using three gene loci- rbcL, matK and ITS2 that was sequenced using a next-generation sequencing (NGS) platform (Illumina Miseq). Furthermore, a classical palynology study for all 20 samples was carried out to evaluate the NGS approach. NGS based approach and pollen microscopic studies were able to detect the most abundant floral components of honey. We investigated the plants that were frequently used by honey bees by examining the results obtained from both the techniques. Microscopic examination of pollens detected plants with a broad taxonomic range covering 26 families. NGS based multigene approach revealed diverse plant species, which was higher than in any other previously reported techniques using a single locus. Frequently found herbaceous species were from the family Poaceae, Myrtaceae, Fabaceae and Asteraceae. The future NGS based approach using multi-loci target, with the help of an improved and robust plant database, can be a potential replacement technique for tedious microscopic studies to identify the polleniferous plants.
\end{abstract}

Keywords: Honey, Multilocus target, DNA barcoding, Palynology

\section{Introduction}

Honey has been used for centuries as a complex natural sweetener having therapeutic properties. Bees obtain pollen and nectar from flowers and hence the plant composition varies due to different topography, climate and farming practices. The knowledge of flora in a region is essential for successful bee keeping, management of bee colonies and production of other bee products.

\footnotetext{
*Correspondence: rc_laha@yahoo.com

${ }^{\dagger}$ Rama Chandra Laha and Surajit De Mandal contributed equally to this work

1 Departments of Botany, Biotechnology and Zoology, School of Life Sciences, Mizoram University, Aizawl, Mizoram 796004, India Full list of author information is available at the end of the article
}

Conventional methods to analyze the association between plants and pollinators depend on time intensive observation of individual interaction (Mitchell et al. 2009). Few methods have been proposed for the determination of botanical and geographical origin of honey. The conventional approach used microscopic observation of pollens present in honey (palynology), which is very tedious and time consuming process. The other common chemical methods based on aroma compounds, free amino acids or minerals and trace element were also developed, but requires sophisticated and expensive instruments (Hermosín et al. 2003; Fernández-Torres et al. 2005; Anklam et al. 1998). Moreover, all these methods provide only limited information on the plant composition of honey samples. While some efforts have 
been made to develop protocols to ascertain the entomological sources of honey (Schnell et al. 2010), most have focused on identifying its plant origin. Past studies have often relied upon diagnostic phytochemicals (Cotte et al. 2004; Tosun 2013) or the study of pollen in honey (melissopalynology) (Alves and Santos 2014). Although the latter approach requires considerable expertise and cannot distinguish many plant species (Kaškonienė and Venskutonis 2010), yet it is a powerful diagnostic tool, especially when used with other methods (Hawkins et al. 2015). However, melissopalynology is ineffective in cases where low value honey is filtered to remove its source pollen and spiked with pollen from the desired monoflora (Kaškonienè and Venskutonis 2010).

With the advancement in next generation sequencing technology, study of the botanical and geographical origin of honey is much easier since it is fast, precise and reliable. Both Roche 454 and Illumina sequencing has been successfully used in analysing mixed species in various applications. Metabarcoding, identification of genera or species present in a composite DNA sample has been introduced by Richardson et al. (2015a) targeting the ITS2 marker using Illumina sequencing technology. This also had higher sensitivity and resolution in identification of plant species than microscopic analysis of the pollen samples. Ion Torrent platform was used to evaluate the DNA barcoding technology for quantifying airborne pollen (Richardson et al. 2015b), whereas pyrosequencing was also successfully used to analyse pollen from honey samples (Sickel et al. 2015; Keller et al. 2015).

Here, we evaluated the botanical composition of honey samples to verify the hypothesis that the metabarcoding will reveal more information congruent with the palynological study. To test this multigene Illumina approach along with microscopic observation were used.

\section{Materials and methods}

Study site and honey sampling

Twenty different honey samples were collected from Aizawl and Champhai districts of Mizoram, an eastern Himalayan biodiversity hotspot, Northeast India. The honey samples were obtained from bee keepers during February to June 2014 (Table 1). Mizoram state is situated in the extreme end of the Himalayan ranges and is predominantly mountainous terrain. The region enjoys a moderate climate, tropical location and due to its high elevation with an annual average rainfall of $250 \mathrm{~cm}$.

\section{Palynological study \\ Preparation of pollen slides from honey: acetolysis method}

One millilitre of honey sample was taken in a test tube and diluted to $10 \mathrm{ml}$ by hot distilled water of $40{ }^{\circ} \mathrm{C}$. The diluted honey was sieved through a mesh of $100 \mu \mathrm{m}$. The suspension thus obtained was centrifuged at $3000 \mathrm{rpm}$ for $5 \mathrm{~min}$. The pellet of pollen sediment was subjected for acetolysis (Louveaux et al. 1978). Pollen grains were examined and identified under the light microscope. Percentage occurrence of pollen was used to determine their frequencies for determining the major and minor honeybee plants. Fresh flower of known plant pollen slides was prepared according to same acetolysis method as reference for identification (Louveaux et al. 1978).

\section{Pollen spectrum study}

The pollen grains were identified using local flora and confirmed by comparing pollen types with reference pollen slides. Based on the frequencies of pollen grain in various honey samples, the pollen count and percentage of pollen types were calculated and pollen spectra were prepared (Erdtman 1960). These pollen types were classified based on the recommendation of the International Commission for bee-Botany: "secondary pollen type (S)"

Table 1 Geographical location of the honey samples used in this study

\begin{tabular}{|c|c|c|c|c|c|c|c|c|c|}
\hline District & Sample ID & Sample location & Latitude & Longitude & District & Sample ID & Sample location & Latitude & Longitude \\
\hline \multirow[t]{10}{*}{ Aizawl } & $\mathrm{A} 1$ & Falkland & $23.73^{\circ}$ & $92.74^{\circ}$ & Champhai & $\mathrm{C} 1$ & Hmunhmeltha & $23.4^{\circ}$ & $93.2^{\circ}$ \\
\hline & $A 2$ & Thuampui & $23.74^{\circ}$ & $92.73^{\circ}$ & & $\mathrm{C} 2$ & N.Khawbung & $23.54^{\circ}$ & $93.31^{\circ}$ \\
\hline & A3 & Tanhril & $23.74^{\circ}$ & $92.67^{\circ}$ & & C3 & Ruantlang & $23.44^{\circ}$ & $93.34^{\circ}$ \\
\hline & A4 & Durtlang & $23.79^{\circ}$ & $92.72^{\circ}$ & & C4 & Zote & $23.49^{\circ}$ & $93.35^{\circ}$ \\
\hline & A5 & Sihphir & $23.81^{\circ}$ & $92.73^{\circ}$ & & C5 & Khawzawl & $23.37^{\circ}$ & $93.12^{\circ}$ \\
\hline & A6 & Hlimen & $23.77^{\circ}$ & $92.66^{\circ}$ & & C6 & Vengsang & $23.47^{\circ}$ & $93.31^{\circ}$ \\
\hline & A7 & Melthum & $23.69^{\circ}$ & $92.72^{\circ}$ & & $C 7$ & Chawngtlai & $23.44^{\circ}$ & $93.19^{\circ}$ \\
\hline & A8 & Maubawk & $23.72^{\circ}$ & $92.69^{\circ}$ & & $\mathrm{C} 8$ & Tlangsam & $23.46^{\circ}$ & $93.34^{\circ}$ \\
\hline & A9 & Sairang & $23.80^{\circ}$ & $92.65^{\circ}$ & & C9 & N.Champhai & $23.45^{\circ}$ & $93.32^{\circ}$ \\
\hline & A10 & Sakawrtuichhun & $23.76^{\circ}$ & $92.67^{\circ}$ & & $\mathrm{C} 10$ & Mualkawi & $23.41^{\circ}$ & $93.33^{\circ}$ \\
\hline
\end{tabular}


(16-45\%), "important minor pollen type (I)" (3-15\%) and "minor pollen type $(\mathrm{M})$ " $(<3 \%)$.

\section{Preparation of honey for DNA extraction}

Honey samples were dissolved in $1 \mathrm{ml}$ sterile water, incubated at $65^{\circ} \mathrm{C}$ for $30 \mathrm{~min}$ followed by centrifugation at $5000 \mathrm{rpm}$ for $10 \mathrm{~min}$. The supernatant was discarded, and the pellet was dried for $5 \mathrm{~min}$ at room temperature and further dissolved in $500 \mu \mathrm{l}$ extraction buffers (100 mM Tris-HCl, $50 \mathrm{mM}$ EDTA, $50 \mathrm{mM} \mathrm{NaCl}, 10 \%$ SDS, pH 7.5). $0.5 \mathrm{~g}$ of sterilized glass beads $(0.5-1 \mathrm{~mm}$ diameter) was added and the pellet was ground with a glass rod for 5-10 min. $100 \mu \mathrm{l}$ DTT $(110 \mathrm{mM})$ and $10 \mu \mathrm{l}$ proteinase $\mathrm{K}(10 \mathrm{mg} / \mathrm{ml})$ were added to the mixture and incubated at $56{ }^{\circ} \mathrm{C}$ for $1 \mathrm{~h}$. A second incubation $\left(65^{\circ} \mathrm{C}\right.$ for overnight) was performed by adding $500 \mu$ l cetyltrimethyl ammonium bromide (CTAB) extraction buffer (20 mM Tris-HCl, pH 8.0, 10 mM EDTA, pH 8.0, 10\% $\mathrm{CTAB}, 5 \%$ polyvinylpyrrolidone), $10 \mu \mathrm{l}$ proteinase $\mathrm{K}$, and $50 \mu \mathrm{l}$ DTT. Phenol-chloroform-isoamyl alcohol $(500 \mu \mathrm{l})$ was added and centrifuged at $10,000 \mathrm{rpm}$ for $10 \mathrm{~min}$. DNA was precipitated using $500 \mu \mathrm{l}$ isopropanol and $100 \mu \mathrm{l}$ sodium acetate $(3 \mathrm{mM}$ ) (Lalhmangaihi et al. 2014). The extracted DNA was checked by agarose gel electrophoresis and stored at $-20^{\circ} \mathrm{C}$ prior to subsequent analysis.

\section{Amplification of the DNA barcode genes}

For Illumina sequencing, all ten honey DNA samples from each district were pooled to make a composite DNA sample $(\mathrm{Chp}=$ composite DNA sample from Champhai district and Azl = composite honey DNA sample from Aizawl district). DNA from the two composite honey DNA samples (Chp and Azl) was amplified using three candidate DNA barcode gene primers: matK, rbcL and ITS2 (Table 2) $(18,19)$. PCR was performed in a total of $50 \mu \mathrm{l}$ reaction volume consisting of $50 \mathrm{ng}$ of DNA, 1X PCR buffer (75 mM Tris- $\mathrm{HCl}(\mathrm{pH} 9.0), 50 \mathrm{mM} \mathrm{KCl}$, $\left.20 \mathrm{mM}(\mathrm{NH} 4)_{2} \mathrm{SO}_{4}\right), 2.5 \mathrm{mM} \mathrm{MgCl}, 0.125 \mathrm{mM}$ of each dNTPs, $0.5 \mu \mathrm{M}$ of each primer and $0.5 \mathrm{U}$ of Taq Polymerase (3B DNA polymerase, 3B Black Bio Biotech India). All
PCR reactions was performed in an Agilent Sure Cycler 8800 using a touchdown amplification profile consisting of an initial denaturation at $95{ }^{\circ} \mathrm{C}$ for 5 min followed by 40 cycles of denaturation at $95^{\circ} \mathrm{C}$ for $2 \mathrm{~min}$, annealing at $65{ }^{\circ} \mathrm{C}$ for $90 \mathrm{~s}$, extension at $72{ }^{\circ} \mathrm{C}$ for 2 min with a final extension at $72{ }^{\circ} \mathrm{C}$ for $10 \mathrm{~min}$. In this touchdown proto$\mathrm{col}$, the annealing temperature was uniformly decreased from $65{ }^{\circ} \mathrm{C}$ to $45^{\circ} \mathrm{C}$ at the rate of $1{ }^{\circ} \mathrm{C}$ per cycle. The PCR products were resolved using $2 \%$ Agarose gel at $120 \mathrm{~V}$ till the samples reached 3/4th of the gel. The gel was visualized under UV light and the image was captured. The PCR products from each sample with the three primers was pooled in an equal concentration and preceded for NGS sequencing.

\section{Illumina sequencing}

An Illumina-compatible library was prepared at Genotypic Technology, Bangalore, India according to manufacturer recommended protocol (Fig. 1). In brief, pooled amplicons were sheared to generate fragments of approximately 200-500 bp in a Covaris micro tube with the E220 system (Covaris, Inc., Woburn, MA, USA). The fragment size distribution was confirmed with Agilent High Sensitivity DNA Tape station (Agilent Technologies, Santa Clara, CA). Next, the fragmented DNA was cleaned up using HighPrep beads (MagBio Genomics, Inc, Gaithersburg, Maryland) followed by end-repair, A-tailing, and ligation of the Illumina multiplexing adapters. The adapter-ligated DNA was cleaned up using HighPrep beads (MagBio Genomics, Inc, Gaithersburg, Maryland). Then, the adapter ligated fragments were subjected to 10 rounds of PCR (denaturation at $98^{\circ} \mathrm{C}$ for 2 min, cycling $\left(98^{\circ} \mathrm{C}\right.$ for $30 \mathrm{~s}, 65^{\circ} \mathrm{C}$ for $30 \mathrm{~s}$ and $72{ }^{\circ} \mathrm{C}$ for $1 \mathrm{~min}$ ) and final extension at $72{ }^{\circ} \mathrm{C}$ for $5 \mathrm{~min}$ ) and the amplicons were purified with HighPrep beads. The Illumina-compatible libraries were quantified with Qubit flourometer and their fragment length distribution was analyzed on Agilent High Sensitivity DNA Tape station (Agilent Technologies, California, USA). The Illumina sequencing was carried out using Illumina Nextseq 500 platform.

Table 2 Primers used for PCR amplification

\begin{tabular}{llll}
\hline Locus & Primer name & Direction & Sequence $\left(\mathbf{5}^{\prime} \mathbf{- 3}^{\prime \mathbf{}} \mathbf{)}\right.$ \\
\hline matK & KIM3 & Forward & CGTACAGTACTTTTGTGTTTACGAG \\
& KIM1 & Reverse & ACCCAGTCCATCTGGAAATCTTGGTTC \\
rbcL & rbcLa & Forward & ATGTCACCACAAACAGAGACTAAAGC \\
& rbcLajf634R & Reverse & GAAACGGTCTCTCCAACGCAT \\
ITS2 & ITS2_3 & Forward & GCATCGATGAAGAACGCAGC \\
& ITS2_4 & Reverse & TCCTCCGCTTATTGATATGC \\
\hline
\end{tabular}


NEXTFlex DNA Sequencing Kit (Cat \#5140-02)

NEXTFlex DNA Barcodes - 48 (Cat \# 514104)

HighPrep ${ }^{\text {TM }}$ PCR (Magbio, \#AC-60050)

High Sensitivity Tape Station Kit (Agilent, \# 5067-5585 (reagents)\# 5067-5584 (tapes))

Nuclease free water (Ambion, \#AM9939)

Covaris ${ }^{\mathrm{TM}}$ S220 System (Life Technologies, \#4465653)

Covaris $^{\mathrm{TM}}$ microTUBE AFA (Life Technologies, \#520045)

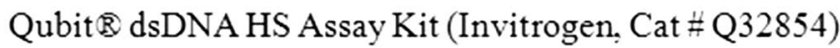

Fig. 1 NEXTFlex DNA sample preparation guide. Illumina-compatible libraries were prepared using the above procedure

\section{Data analysis}

The Illumina raw reads were quality checked using Fast QC followed by adapter clipping and trimming of low quality bases trimming towards $3^{\prime}$-end using fastx toolkit (Andrews and Fast 2010; Martin 2011; Gordon and Hannon 2010). De novo assemblies of quality filtered reads were carried out using velvet assembler (Zerbino and Birney 2008). The kmer value was optimized to select the best kmer for the assembly. The contigs were analysed by BLAST against NCBI Viridiplantae database to annotate the sequences in the assembly (Altschul et al. 1990). The annotation results were analysed and removed any duplicates to identify the species present in the sample.

\section{Results}

\section{Pollen spectrum analysis of honey samples}

Polleniferous plants were classified based on nature of vegetation such as wild plants, horticultural plants, ornamental plants and agricultural plants. Under wild plants, 42 species were identified majority of them taxonomically belongs to the family Fabaceae followed by Asteraceae, Euphorbiaceae, Malvaceae, Myrtaceae, Lamiaceae, Rosaceae, Combretaceae, Verbenaceae, Betulaceae, Polygonaceae, Amaranthaceae, Oxalidaceae, Bombacaceae, Fagaceae, Rubiaceae, Cyperaceae, Elaeocarpaceae, Lythraceae, Solanaceae and Bignoniaceae. Eleven species falls under the horticultural plants taxonomically classified under the family Myrtaceae, Caricaceae, Rutaceae, Arecaceae, Rubiaceae, Lythraceae, Anacardiaceae, Musaceae and Vitaceae. Ornamental plants consist of 8 species, major two falls under the family Malvaceae followed by each from Asteraceae, Rubiaceae, Euphorbiaceae and Rosaceae. While agricultural plants were represented by 15 species classified under the family Cucurbitaceae, Brassicaceae Poaceae, Malvaceae, Apiaceae, Moringaceae, Solanaceae (Additional file 1: Table $\mathrm{S} 1)$.

\section{Analyses of pollen types}

In the present study, the study area consists of mixed vegetation with multi-floral honey samples. Analysis of pollen count revealed that some plant species were more frequently represented in the honey sample. This is due to their readily available nectar coming from longer flowering periods for the particular plant species in available in the studied area. During the study period, the secondary pollen type (16-45\%) was dominated by the families Fabaceae, Asteraceae and Myrtaceae. Other family identified under the secondary pollen types were Poaceae, Apiaceae, Arecaceae, Betulaceae, Brassicaceae, Caricaceae,

\section{Table 3 Sequence characteristics of the composite honey} samples

\begin{tabular}{lcc}
\hline Sequence characteristics & Aizawl dt. & Champhai dt. \\
\hline Kmer & 123 & 127 \\
Number of contigs & 43 & 30 \\
Assemply length & 32,855 & 16,832 \\
N50 contigs & 16 & 12 \\
N50 length & $673 \mathrm{bp}$ & $625 \mathrm{bp}$ \\
Min contig length & 281 & 389 \\
Max contig length & 3818 & 920 \\
Avg contig length & 631 & 621 \\
\hline
\end{tabular}


Table 4 Plant species found in the composite honey sample of Aizawl using NGS technology

\begin{tabular}{|c|c|c|c|c|c|}
\hline S. no. & Name of the plant & Family & $r b c l$ & matK & ITS2 \\
\hline 1 & Actinidia sps. & Actinidiaceae & - & - & + \\
\hline 2 & Actinidia chinensis & Actinidiaceae & - & - & + \\
\hline 3 & Anaphalis nepalensis & Asteraceae & - & - & + \\
\hline 4 & Arachis hypogaea & Fabaceae & - & - & + \\
\hline 5 & Augusta sps. & Rubiaceae & + & - & - \\
\hline 6 & Barringtonia asiatica & Lecythidaceae & - & - & + \\
\hline 7 & Betula pendula & Betulaceae & - & - & + \\
\hline 8 & Brassica napus & Brassicaceae & - & - & + \\
\hline 9 & Capsicum annum & Solanaceae & - & - & + \\
\hline 10 & Ceiba pentandra & Malvaceae & - & + & - \\
\hline 11 & Celastrus strigillosus & Celestraceae & - & + & - \\
\hline 12 & Cicer arietinum & Fabaceae & - & - & + \\
\hline 13 & Citrus maxima & Rutaceae & + & - & - \\
\hline 14 & Coffea arabica & Rubiaceae & - & + & - \\
\hline 15 & Cordia dentate & Boraginaceae & + & - & - \\
\hline 16 & Cordia myxa & Boraginaceae & - & + & - \\
\hline 17 & Coriandrum sativum & Apiaceae & - & - & + \\
\hline 18 & Corymbia torelliana & Myrtaceae & - & - & + \\
\hline 19 & Entada rheedei & Fabaceae & - & + & - \\
\hline 20 & Erythrina subumbrans & Fabaceae & - & - & + \\
\hline 21 & Exbucklandia populnea & Hamamelidaceae & - & - & + \\
\hline 22 & Helianthus eggertii & Asteraceae & - & + & - \\
\hline 23 & $\begin{array}{l}\text { Lecomtella madagas- } \\
\text { cariensis }\end{array}$ & Poaceae & + & - & - \\
\hline 24 & Leucaena leucocephala & Fabaceae & - & + & - \\
\hline 25 & Mikania micrantha & Asteraceae & - & + & - \\
\hline 26 & Pyrus pyrifolia & Rosaceae & + & - & - \\
\hline 27 & Pyrus ussuriensis & Rosaceae & - & + & - \\
\hline 28 & Quercus gilva & Fagaceae & - & - & + \\
\hline 29 & Rhoiptelea chiliantha & Juglandaceae & + & - & - \\
\hline 30 & Salacia typhina & Celastraceae & - & + & - \\
\hline 31 & Smilax sps. & Smilacaceae & - & + & - \\
\hline 32 & Solanum carolinense & Solanaceae & - & - & + \\
\hline 33 & Solanum lycopersicum & Solanaceae & - & - & + \\
\hline 34 & Solanum pennellii & Solanaceae & - & - & + \\
\hline 35 & Sophora tetraptera & Fabaceae & - & - & + \\
\hline 36 & Trema tomentosa & Cannabaceae & - & + & - \\
\hline 37 & Tripterygium regelii & Celestraceae & - & + & - \\
\hline 38 & Triticum dicoccon & Poaceae & + & - & - \\
\hline 39 & Ugni molinae & Myrtaceae & - & + & - \\
\hline 40 & Vitis vinifera & Vitaceae & - & - & + \\
\hline 41 & Wahlenbergia augustifolia & Campanulaceae & - & + & - \\
\hline 42 & Wahlenbergia gloriosa & Campanulaceae & + & - & - \\
\hline 43 & Wendlandia tinctoria & Rubiaceae & - & - & + \\
\hline
\end{tabular}

Combretaceae, Cucurbitaceae, Cyperaceae, Datiscaceae, Euphorbiaceae, Lythraceae, Malvaceae, Moringaceae, Musaceae and Rubiaceae. Plant species identified under
Table 5 Plant species found in the composite honey sample of Champhai using NGS technology

\begin{tabular}{|c|c|c|c|c|c|}
\hline S. no. & Name of the plant & Family & $r b c L$ & matK & ITS2 \\
\hline 1 & Ageratina adenophora & Asteraceae & - & - & + \\
\hline 2 & Ageratum conyzoides & Asteraceae & + & - & - \\
\hline 3 & Ageratum houstonianum & Asteraceae & - & + & - \\
\hline 4 & Alangium chinense & Cornaceae & - & + & - \\
\hline 5 & Albizia procera & Fabaceae & - & - & + \\
\hline 6 & Archidendron hirsutum & Fabaceae & + & - & - \\
\hline 7 & Arenga pinnata & Arecaceae & + & - & - \\
\hline 8 & Bambusa oldhamii & Poaceae & - & - & + \\
\hline 9 & Bischofia javanica & Phyllanthaceae & + & - & - \\
\hline 10 & Calamus caryotoides & Arecaceae & - & - & + \\
\hline 11 & Calamus castaneus & Arecaceae & - & + & - \\
\hline 12 & Callistemon citrinus & Myrtaceae & + & - & - \\
\hline 13 & Carya hunanensis & Juglandaceae & - & + & - \\
\hline 14 & Coffea arabica & Rubiaceae & - & + & - \\
\hline 15 & Dimocarpus longan & Sapindaceae & + & - & - \\
\hline 16 & Eucalyptus melliodora & Myrtaceae & - & - & + \\
\hline 17 & Helianthus maximiliani & Asteraceae & - & + & - \\
\hline 18 & Juglans olanchana & Juglandaceae & - & + & - \\
\hline 19 & Juglans regia & Juglandaceae & - & + & - \\
\hline 20 & Mikania micrantha & Asterceae & - & - & + \\
\hline 21 & Paneroa stachyofolia & Asterceae & - & + & - \\
\hline 22 & Prunus cerasifera & Rosaceae & - & + & - \\
\hline 23 & Psidium guajava & Myrtaceae & - & + & - \\
\hline 24 & Schima wallichii & Theaceae & - & + & - \\
\hline 25 & Sorghum halepense & Poaceae & + & - & - \\
\hline 26 & Tetrameles nudiflora & Tetramelaceae & - & + & - \\
\hline 27 & Thysanolaena latifolia & Poaceae & - & - & + \\
\hline 28 & Trema sps. & Cannabiaceae & + & - & - \\
\hline 29 & Wendlandia formosana & Rubiaceae & - & + & - \\
\hline 30 & Zanthoxylum piperitum & Rutaceae & - & - & + \\
\hline
\end{tabular}

the important minor pollen types (3-15\%) were mostly represented by family Fabaceae, Asteraceae, Malvaceae, Myrtaceae, Cucurbitaceae, Euphorbiaceae, Rubiaceae, Brassicaceae, Combretaceae, Lamiaceae, Poaceae, Rosaceae, Solanaceae and Verbenaceae. While minor pollen types $(<3 \%)$ were dominated by the family Fabaceae followed by Asteraceae, Malvaceae, Myrtaceae, Cucurbitaceae and Euphorbiaceae and Rubiaceae (Additional file 1: Table S1). Other detected families under minor pollen types were represented by $\leq 3$ plant species. Plant species identified under all the pollen types is shown in Additional file 1: Table S1.

\section{Identification of plant species using NGS technology}

Present analysis detected 52 and 30 contigs from Aizawl and Champhai district respectively (Table 3). Based upon the NGS study, a total of 73 plant species were 
a

Palynological study QTL-omics study

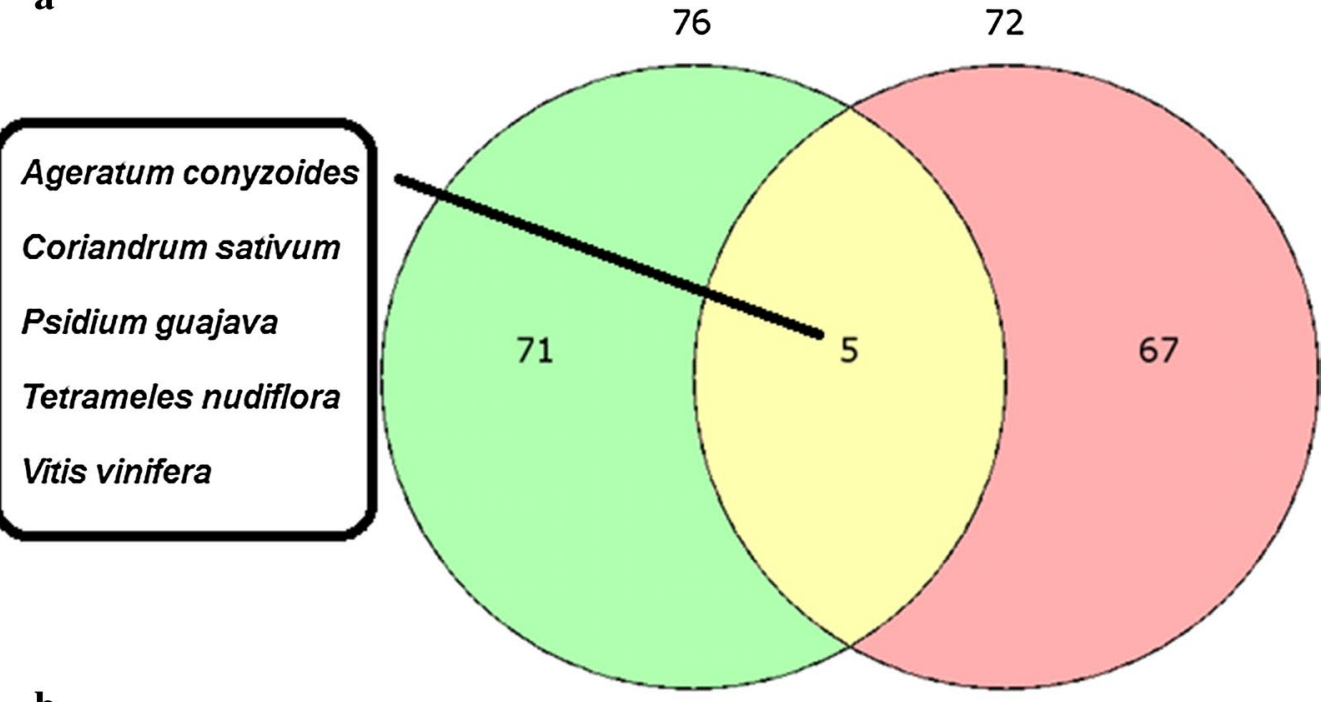

b

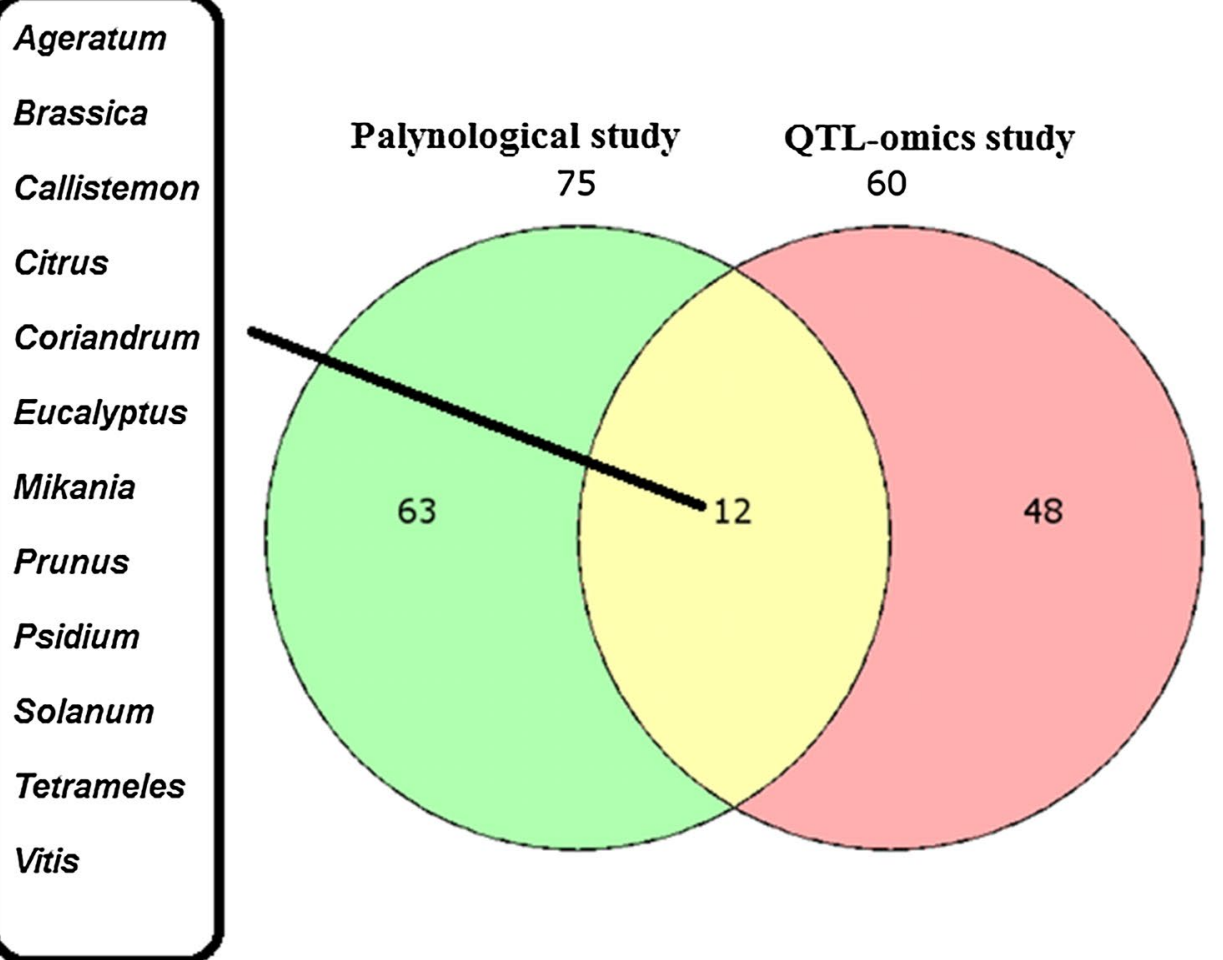

Fig. 2 Unique and shared plant species identified in palynological and QTLomics in a Aizawl district. b Champhai district of Mizoram, Northeast India

identified in two composite honey metagenome from two different districts of Mizoram, North-East India (Tables 4, 5). It was found that all the three genes used during NGS study (rbcL, matK, and ITS2) were the important marker for identification of plant species. A total of 16 plants were identified using $r b c L$ gene,
29 species using matK and 29 species using ITS2 gene sequences.

At the species level, only five plant species were found to be the common in both palynological and NGS studies, whereas 12 common genera were identified in both the approaches. This might be due to the inadequate 
information on gene information, which hinders the identification of all the polleniferous plant species using NGS approach (Fig. 2a, b). The only species Coffea arabica was found to be commonly present in both Champhai and Aizawl district.

\section{Discussion}

Next generation sequencing (NGS) has been successfully used for taxonomic assessment of polleniferous plant from honey samples (Richardson et al. 2015a, b; Sickel et al. 2015; Keller et al. 2015). Present study combines traditional microscopic analysis with DNA metabarcoding to understand the scope of identifying the polleniferous plants from honey samples.

The two approach for study DNA metabarcoding identified 74 number of polliniferous plant species from the two districts of the state Mizoram, while melissopalynological study identified 76 numbers of plant species. Hence, the two techniques are important and relevant for identifying the polliniferous plants. Rechardson et al. (2015b) studied honey pollen samples using three metabarcoding targeting (ITS2, matK, and $r b c L$ ) as well as by light microscopy and found a significant correlation between the relative abundance of the pollen types in the studied samples with both metabarcoding and microscopic observation (Richardson et al. 2015b). They also denoted that multilocus metabarcoding is more reliable than single-locus analyses (Sickel et al. 2015).

Mizoram falling under the Indo-Burma Biodiversity hotspot zone is possessing large forest coverage. Due to Jhum cultivation, forests in Mizoram are degraded and analyzing pollen present in honey samples will help to understand the effect of such anthropogenic activities that affect the diversity of plant species and floral resource quality. This will also help in habitat restoration and conservation efforts (Myers et al. 2000; De Mandal et al. 2016). In both the approaches, most of the plant species did not show similar taxonomic placement up to the genus level or by the species level. This might be due to the lack of databases for the polleniferous plants of the studied region or lack of sufficient information for taxonomic identification.

Melissopalynology study the microscopic analysis of pollen content of the honey from the locality, with field study involving phenology provide reliable information regarding the floral types which serve as the pollen sources for the honey bees. Pollen found in honey is used to determine the honey types, quality control and to ascertain whether honey is adulterated or not (Villanueva 1994). From the pollen spectra, it was observed that the two districts include both naturalized flora as well as cultivated crops. It also gives a wider knowledge of bee preferences in local floral. Generally, entomophilic plants were numerous in the pollen spectrum of each honey sample studied and the honey from the source localities was fairly rich in pollen types. The microscopical analysis of honey is important in establishing the seasonal pollen spectra of honey from various climatic and geographical areas, for evaluation of honey originated from various physiographic region (Chaturvedi 1983). In the present study, many pollens were unidentifiable, which reflects the drawbacks in the taxonomical classification system.

The outcome of this study depicts the link between honey bees and its foraging plant species, honeybee foraging plant diversity using a DNA metabarcoding approach. In the present study, palynology data has identified many plant species that were not identifiable by NGS. This might be because of incomplete plant database and future research should focus on strengthening the information on the plant DNA barcode genes. In our study, majority of the pollen were unidentifiable using palynology which might represent many other plant species. These plant species might have been identified using the NGS approach. It will be of immense value for the development of beekeeping industry for the studied area and for the entire region and this information could be used to selectively grow native plants that are important for the honey bees. The present study will be helpful for identifying different floral sources used by honey bees and improved the conservation of economically viable plants.

\section{Additional file}

Additional file 1: Table S1. Palynological analysis of the honey samples.

\section{Abbreviations}

rbcL: ribulose-bisphosphate carboxylase gene; MatK: maturase K gene; ITS: internal transcribed spacer; DNA: deoxyribonucleic acid; PCR: polymerase chain reaction; NGS: next-generation sequencing.

\section{Authors' contributions}

Conceived and designed the experiments: SDM, RCL and NSK. Performed the experiments: SDM and LR. Analyzed the data: SDM and NSK. Contributed reagents/materials/analysis tools: RCL and NSK. Wrote the paper: SDM, RCL and NSK. Critically reviewed and corrected NSK, SDM, RCL, RM, GG and RS. All authors read and approved the final manuscript.

\section{Author details}

${ }^{1}$ Departments of Botany, Biotechnology and Zoology, School of Life Sciences, Mizoram University, Aizawl, Mizoram 796004, India. ${ }^{2}$ Department of Biotechnology, Bharathiar University, Coimbatore 641046, India. ${ }^{3}$ Genotypic Technologies, Bangalore, India. ${ }^{4}$ QTLomics Technologies, Bangalore, India.

\section{Acknowledgements}

Authors thankful to the DBT-Bioinformatics Infrastructure Facility, Mizoram University for providing computing facilities for NGS data analysis.

\section{Competing interests}

The authors declare that they have no competing interests. 


\section{Availability of data and materials}

The raw data obtained had been deposited in the NCBI Sequence Read Archive (SRA) with the Bio Project ID-PRJNA335943.

\section{Funding}

This research was sponsored by a Twining Grant (BT/423NE/TBP/2013) from the Department of Biotechnology, Govt. of India, New Delhi.

\section{Publisher's Note}

Springer Nature remains neutral with regard to jurisdictional claims in published maps and institutional affiliations.

Received: 9 May 2017 Accepted: 12 June 2017

Published online: 24 June 2017

\section{References}

Altschul SF, Gish W, Miller W, Myers EW, Lipman DJ (1990) Basic local alignment search tool. J Mol Biol 215(3):403-410

Alves RD, Santos FD (2014) Plant sources for bee pollen load production in Sergipe, northeast Brazil. Palynology 38(1):90-100

Andrews SF, Fast QC (2010) A quality control tool for high throughput sequence data

Anklam E, Lipp M, Radovic B, Chiavaro E, Palla G (1998) Characterisation of Italian vinegar by pyrolysis-mass spectrometry and a sensor device ('electronic nose'). Food Chem 61(1):243-248

Chaturvedi MI (1983) Pollen analysis of autumn honeys of Kumaon region. Proc Indian Nat Sci Acad 49:125-133

Cotte JF, Casabianca H, Giroud B, Albert M, Lheritier J, Grenier-Loustalot MF (2004) Characterization of honey amino acid profiles using high-pressure liquid chromatography to control authenticity. Anal Bioanal Chem 378(5):1342-1350

De Mandal S, Panda AK, Bisht SS, Kumar NS (2016) MiSeq HV4 16 S rRNA gene analysis of bacterial community composition among the cave sediments of Indo-Burma biodiversity hotspot. Environ Sci Pollut Res 23:12216-12226

Erdtman G (1960) The acetolysis method. A revised description. Svensk Bot Tidsk 54:561-564

Fernández-Torres R, Perez-Bernal JL, Bello-Lopez MA, Callejon-Mochon M Jimenez-Sanchez JC, Guiraúm-Pérez A (2005) Mineral content and botanical origin of Spanish honeys. Talanta 65(3):686-691

Gordon A, Hannon G (2010) Fastx-toolkit. FASTQ/A short-reads preprocessing tools (unpublished). http://hannonlab.cshl.edu/fastx toolkit

Hawkins J, de Vere N, Griffith A, Ford CR, Allainguillaume J, Hegarty MJ, Baillie L, Adams-Groom B (2015) Using DNA metabarcoding to identify the floral composition of honey: a new tool for investigating honey bee foraging preferences. PLoS ONE 10(8):e0134735

Hermosín I, Chicón RM, Cabezudo MD (2003) Free amino acid composition and botanical origin of honey. Food Chem 83:263-268

Kaškonienè V, Venskutonis PR (2010) Floral markers in honey of various botanical and geographic origins: a review. Compr Rev Food Sci Food Saf 9(6):620-634

Keller A, Danner N, Grimmer G, Ankenbrand M, Ohe K, Ohe W, Rost S, Härtel S, Steffan Dewenter I (2015) Evaluating multiplexed next generation sequencing as a method in palynology for mixed pollen samples. Plant Biol 17(2):558-566

Lalhmangaihi R, Ghatak S, Laha R, Gurusubramanian G, Kumar NS (2014) Protocol for optimal quality and quantity pollen DNA isolation from honey samples. J Biomol Tech 25(4):92

Louveaux J, Maurizio A, Vorwohl G (1978) Methods of melissopalynology. Bee World 59(4):139-157

Martin M (2011) Cutadapt removes adapter sequences from high-throughput sequencing reads. EMBnet 17(1):10

Mitchell RJ, Irwin RE, Flanagan RJ, Karron JD (2009) Ecology and evolution of plant-pollinator interactions. Ann Bot 103:1355-1363

Myers N, Mittermeier RA, Mittermeier CG, Da Fonseca GA, Kent J (2000) Biodiversity hotspots for conservation priorities. Nature 403(6772):853-858

Richardson RT, Lin CH, Quijia JO, Riusech NS, Goodell K, Johnson RM (2015a) Rank-based characterization of pollen assemblages collected by honey bees using a multi-locus metabarcoding approach. Appl Plant Sci 3(11):1500043

Richardson RT, Lin CH, Sponsler DB, Quijia JO, Goodell K, Johnson RM (2015b) Application of ITS2 metabarcoding to determine the provenance of pollen collected by honey bees in an agroecosystem. Appl Plant Sci 3(1):1400066

Schnell IB, Fraser M, Willerslev E, Gilbert MT (2010) Characterisation of insect and plant origins using DNA extracted from small volumes of bee honey. Arthropod Plant Interact 4(2):107-116

Sickel W, Ankenbrand MJ, Grimmer G, Holzschuh A, Härtel S, Lanzen J, SteffanDewenter I, Keller A (2015) Increased efficiency in identifying mixed pollen samples by meta-barcoding with a dual-indexing approach. BMC Ecol 15(1):20

Tosun M (2013) Detection of adulteration in honey samples added various sugar syrups with $13 \mathrm{C} / 12 \mathrm{C}$ isotope ratio analysis method. Food Chem 138(2):1629-1632

Villanueva GR (1994) Nectar sources of European and Africanized honey bees (Apis mellifera L.) in the Yucatán peninsula, Mexico. J Appl Biol Sci 33(1):44-58

Zerbino DR, Birney E (2008) Velvet: algorithms for de novo short read assembly using de Bruijn graphs. Genome Res 18(5):821-829

\section{Submit your manuscript to a SpringerOpen ${ }^{\circ}$ journal and benefit from:}

- Convenient online submission

- Rigorous peer review

- Open access: articles freely available online

- High visibility within the field

- Retaining the copyright to your article

Submit your next manuscript at springeropen.com 